\title{
Pokój z Iwanem. Rosja jako siła opatrznościowa w propagandzie Państw Centralnych doby Wielkiej Wojny
}

Prowadzony i wspomagany przez personifikacje swego przeznaczenia, bohater kontynuuje wyprawę i [...] dociera do „strażnika progu”, stojącego u wejścia do strefy spotęgowanej mocy. [...] Za [nią] rozciąga się ciemność, skrywająca rzeczy nieznane i groźne. [...] Rejony nieznane [...] są polem dla niczym nie skrępowanej projekcji treści nieświadomości. Kazirodcze libido i ojcobójcze destrudo kierują się stamtąd z powrotem do jednostki i jej społeczności, przybierając formy przywodzące na myśl groźby gwałtu i przemocy oraz niebezpiecznej rozkoszy.

Joseph Campbell ${ }^{1}$

Otwierając w grudniu 2007 roku berlińską wystawę Nasi Rosjanie - nasi Niemcy ${ }^{2}$, niemiecki minister spraw zagranicznych Frank-Walter Steinmeier stwierdził:

* Doktor, Katedra Teorii i Historii Stosunków Międzynarodowych, Wydział Studiów Międzynarodowych i Politologicznych, Uniwersytet Łódzki.

1 J. Campbell, Bohater o tysiącu twarzy, Poznań 1997, s. 68-69.

2 Pełen tytuł wystawy: Nasi Rosjanie - nasi Niemcy. Wizerunki Innego, 1800-2000. Wystawa była otwarta dla zwiedzających na zamku Charlottenburg w dniach 8.12.2007-2.03.2008. 
Niemców i Rosjan łączy długa, tragiczna, krwawa i bezprecedensowa w skali dziejów historia. Przynajmniej od połowy XVIII w. stan relacji niemiecko-rosyjskich decydował nie tylko o losach obu krajów, lecz również naszych sąsiadów w Europie Środkowej i Wschodniej oraz innych narodów i państw. Bez przesady powiedzieć można, że w dwu ostatnich stuleciach stosunki między Niemcami a Rosją odgrywały istotną, a często wręcz rozstrzygającą rolę w przełomowych momentach europejskiej historii ${ }^{3}$.

Wspomniana wypowiedź znajduje potwierdzenie zarówno w myśleniu politycznym współczesnych Niemców, jak i w historiozoficznych rozważaniach formułowanych w Niemczech w minionych stuleciach. Upraszczając, relacje z Rosją jawią się Niemcom w dwóch kontekstach. Kraj ten to z jednej strony Wschód, który należy odwracać od barbarzyństwa, cywilizować i poskramiać, z drugiej zaś niezwyciężony, potężny kolos, który nie raz stał się siłą sprawczą w niemieckiej historii.

W świetle faktów, lecz także wiedzy potocznej, Rosja w dziejach Niemiec kilkakrotnie odegrała rolę deus ex machina. Śmierć carycy Elżbiety w 1762 roku i wstąpienie na tron Piotra III spowodowały wycofanie się Rosji z koalicji antypruskiej, następnie zaś w ogóle z wojny siedmioletniej. Wydarzenie to w ostatniej chwili uratowało Prusy przed klęską militarną i przeszło do historii jako Cud domu brandenburskiego. W okresie napoleońskim w pamięci Niemców zapisał się obraz armii rosyjskiej jako potęgi, która wyzwoliła Europę spod okupacji francuskiej. W erze Bismarcka, który mawiał, że istota niemieckiej dyplomacji polega na wynegocjowaniu dobrej umowy z Rosją, stosunki między obu krajami porównywano do relacji małżeńskich. W 1866 roku minister spraw zagranicznych Prus Otto von Manteuffel państwo to przyrównał do żony don Giovanniego, donny Elwiry: „dawnej, legalnej”, kochającej, tej, która czeka tylko „na słodkie

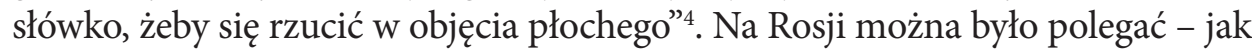
argumentowali dyplomaci - podczas gdy relacje z krajami takimi jak Włochy czy Francja przyrównywano do flirtu lub niefortunnego romansu ${ }^{5}$.

W XX wieku ratunkiem dla osamotnionej politycznie Republiki Weimarskiej okazał się układ o współpracy z ZSRR, podpisany w Rapallo (1922), dla Hitlera zaś - zabezpieczający przed wojną na dwa fronty - układ Ribbentrop-Mołotow (1939). Wreszcie, klimat gorbaczowowskiej pierestrojki i „nowego myślenia” dały impuls do obalenia władzy komunistycznej w NRD, następnie zaś umożliwiły ponowne zjednoczenie Niemiec (1990). O wyjątkowej roli odgrywanej przez Rosję mówi się w Niemczech również obecnie. Politycy, nade

3 K. Janeke (red.), Unsere Russen, unsere Deutschen. Bilder vom Anderen 1800 bis 2000, Berlin 2008, s. 7.

4 J. Klaczko, Dwaj kanclerze, [w:] idem, Dwaj kanclerze i inne studia dyplomatyczne, Kraków 2009, s. 152.

5 Ibidem. 
wszystko lewicowi, lecz nie tylko, reprezentują pogląd, zgodnie z którym jedynym akceptowalnym systemem globalnych powiązań jest wielobiegunowość, czyli świat, w którym respektuje się interesy wszystkich ważnych mocarstw, w tym Federacji Rosyjskiej.

W wypowiedziach niemieckich żurnalistów i polityków silnie obecna jest również świadomość krzywd, wyrządzonych Rosji radzieckiej w czasie ostatniej wojny, a także przekonanie, że Niemcy nie mają prawa występować wobec tego państwa w roli oskarżyciela. 27 stycznia 2014 roku, w 70. rocznicę przerwania blokady Leningradu, prezydent RFN Joachim Gauck w liście do prezydenta Rosji Władimira Putina napisał, iż pamięć o wojnie totalnej przeciw ZSRR napełnia Niemców głębokim wstydem i smutkiem ${ }^{6}$. Z drugiej strony, 1 września 2014 roku, w związku z wydarzeniami na Ukrainie, Gauck nazwał Rosję krajem „żądnym wojny” i zachowaniem tym wywołał burzliwą krytykę prasy niemieckiej, która oskarżyła go o ignorancję, brak wrażliwości historycznej i dążenie do wzniecenia nowych wojen?

Statystyczny Niemiec nie lubi Rosjan i obawia się prowadzonej przez nich polityki ${ }^{8}$. Dobrym tego przykładem jest sposób postrzegania działań Władimira Putina. Prezydentowi Rosji przypisuje się cechy takie jak nieprzewidywalność i żądza władzy ${ }^{9}$, na dodatek zaś uważa się go za polityka bardziej wpływowego niż Angela Merkel i niekoniecznie liczącego się z jej zdaniem ${ }^{10}$. $Z$ drugiej strony, Rosja jest dla Niemców mocarstwem, którego nie wolno lekceważyć, siłą zdającą się wymykać ocenom w kategoriach dobra i zła, przyjaźni lub wrogości, obcości lub bliskości cywilizacyjno-kulturowej. I vice versa. Zaskakująco wielu Rosjan wybaczyło Niemcom ciemne karty wzajemnej historii i wyraża nadzieję na trwałą, stabilną wzajemną współpracę, a politycy lubią słuchać zapewnień, że „Rosja jest i pozostanie najważniejszym sąsiadem Niemiec na Wschodzie"11.

6 Waga tej rocznicy została podkreślona w ten sposób, iż uczczono ją w Niemczech w tym samym czasie co Dzień Pamięci o Holocauście; https://www.evangelisch.de/inhalte/91843/27-01-2014/gauck-erinnerung-leid-der-russen-im-zweiten-weltkrieg-wach -halten [dostęp: 1.07.2015].

7 http://www.freundederkuenste.de/aktuelles/reden-ist-silber/meinung/joachim-gauckmissbraucht-sein-amt-konstantin-wecker-und-rainer-kahni-sind-empoert.htm [dostęp: 10.07.2015].

8 http://www.welt.de/reise/article128791869/Warum-Russen-die-unbeliebtesten-Touristen-sind.html [dostęp 1.07.2015]; http://de.statista.com/statistik/daten/studie/177126/ umfrage/personengruppen-die-als-nachbarn-unangenehm-waeren/ [dostęp: 1.07.2015].

9 http://de.statista.com/statistik/daten/studie/2714/umfrage/politiker-mit-einfluss-auf -internationaler-ebene/ [dostęp: 1.07.2015].

$10 \mathrm{http}: / / d e . s t a t i s t a . c o m / s t a t i s t i k / d a t e n / s t u d i e / 292792 /$ umfrage/umfrage-zu-charaktereigenschaften-von-wladimir-putin/ [dostęp: 1.07.2015].

11 Słowa byłego kanclerza Niemiec Helmuta Kohla, wypowiedziane na spotkaniu z Władimirem Putinem 13.10.2005. P. Rachtan, Rosja -Niemcy, dwaj sasiedzi, http://kontrateksty. 
Niemcom zdarza się również postrzegać dylematy polityki zagranicznej Rosji przez pryzmat własnych doświadczeń i analogicznie je usprawiedliwiać. Przykładowo, mówiąc o rosyjskiej krytyce rozszerzania NATO na wschód, sięgają do argumentów dotyczących Einkreisungsängste, czyli obaw przed zagrożeniem ze strony sąsiadów, stosujących politykę „okrążenia”, prowadzącego do klinczu. Politykę Rosji, widzianą przez ten pryzmat, postrzega się więc jako reaktywną, a państwo rosyjskie jako niezainteresowane angażowaniem się w konflikt, niebędące jego inicjatorem ani spiritus movens wydarzeń.

\section{Pokój z Iwanem}

W poniższych rozważaniach omówię jeden z kluczowych, niewspomnianych wcześniej momentów w historii, który stał się kanwą do odrodzenia, utrwalenia i wzbogacenia wizerunku Rosji jako niewidzialnej ręki opatrzności, nie tylko w Niemczech, lecz również w innych częściach Europy.

Wydarzeniem tym było raptowne wycofanie się Rosji z działań militarnych podczas I wojny światowej i zawarcie separatystycznego pokoju z państwami centralnymi. Trauma Wielkiej Wojny doprowadziła, szczególnie w Niemczech, do wzbierającego z bezprecedensową siłą wołania o pokój, zaś apele te znalazły największe wsparcie w pacyfistycznych hasłach, głoszonych przez bolszewików. W ten sposób Rosja, jeden z głównych wrogów państw centralnych, po rewolucji październikowej stała się, niespodziewanie i w najbardziej pożądanym momencie, ich największym sojusznikiem.

Omawiając reakcję niemieckiego społeczeństwa na wspomnianą koniunkcję zdarzeń, pragnę podjąć się odpowiedzi na szereg nasuwających się w związku z nią zagadnień:

- Jakie narracje związane z Rosją dominowały w społeczeństwie niemieckim Anno Domini 1917-1918?

- Czym różniły się one od narracji tworzonych w innych państwach centralnych - na potrzeby austriackich i bułgarskich dyskursów propagandowych - a w czym je przypominały?

- Czym uwarunkowana była taka właśnie specyfika omawianych obrazów?

W moim przekonaniu, w pierwszej kolejności klucz do odpowiedzi na wyżej postawione pytania leży $\mathrm{w}$ zrozumieniu uniwersalnych mechanizmów związanych $\mathrm{z}$ kreowaniem wizerunków przyjaciół i wrogów w dobie wojny i propagandy wojennej. Przy założeniu, że jednym z głównych celów propagandy jest afirmacja „swoich”, nie ulega wątpliwości, że zabieg taki musi wiązać się z przynajmniej

$\mathrm{pl} /$ index.php?action=show\&type=quick\&page $=77$ [dostęp: 23.04 .2016 ]; por. G. Gromadzki i in., Ludzie-historia-polityka. Polska i Niemcy w oczach Rosjan, Warszawa 2012, s. 28-37. 
względną deprecjacją Innych/Obcych. Po drugie, agitacja musi być przekonująca, $\mathrm{z}$ tego powodu zaś nie ma innego wyjścia, jak odwoływać się do utrwalonych prawd i nie wycofywać się z wcześniej głoszonych twierdzeń.

Harold D. Lasswell zauważył, że utożsamiamy się z tą propagandą, która solidaryzuje się z wyznawanymi przez nas wartościami i w analogiczny sposób - przez pryzmat przekonania o podzielanej lub nie wspólnocie wartości - waloryzujemy innych. Wrogiem staną się ci, co do których uwierzymy, że wyglądają, myślą i zachowują się inaczej od nas, natomiast partnerami, przyjaciółmi, „swojakami” ci, którzy jawić się nam będą niczym odbicie nas samych ${ }^{12}$. Na subiektywny, afektywny charakter naszych poglądów zwrócił też uwagę m.in. Jacques Ellul. Argumentuje on, iż najbardziej skuteczną propagandą jest ta odwołująca się do mitów, symboli, emocji, nie zaś do inteligencji odbiorcy ${ }^{13}$.

Jedną z głównych zasad propagandy jest więc nienegowanie ustalonych, zracjonalizowanych, trwałych opinii, stereotypów, wzorców zachowań. Na podobnej zasadzie, przekonań nie da się stworzyć z niczego, bez odwołania do idei zawartych w ogólnie znanych symbolach, odniesieniach kulturowych, mitach ${ }^{14}$.

Ellul podkreśla również, że propaganda $\mathrm{z}$ natury nie służy ulepszaniu, humanizowaniu człowieka, lecz legitymizacji jego pierwotnych instynktów. $\mathrm{Z}$ tego powodu musi ona odwoływać się do powszechnie podzielanych uczuć, najbardziej rozpowszechnionych idei, najprymitywniejszych wzorców. Mając na uwadze nawyki i potrzeby zwykłego człowieka, musi przemawiać za pomocą prostych, jednoznacznych, oczekiwanych przez społeczeństwo przekazów, np. „ufaj swoim przywódcom”, „bądź dumny ze swojego kraju”, „nienawidź i miej w pogardzie swych wrogów"15. Jednym z najszybciej i najbardziej skutecznie wpajanych uczuć jest nienawiść. Obfite żniwo zbiera ona zwłaszcza wtedy, gdy doświadczamy nieszczęść; wówczas katartyczną moc daje nam przypisanie własnych klęsk i win Innym oraz utwierdzenie się w przekonaniu, że nasze problemy znikną, gdy tylko wspomniani Inni zostaną uśmierceni ${ }^{16}$.

Teoretycy propagandy zauważają również, że utrwalone przekonania, uprzedzenia, stereotypy są bardzo oporne na zmiany, wręcz niemożliwe do wykorzenienia ${ }^{17}$. Przykładowo, w trakcie wojny role i wizerunki walczących stron są z zasady ściśle rozdzielone, a państwa walczące przeciw sobie nie stają się znienacka przyjaciółmi ${ }^{18}$. To samo odnosi się do intensywności uczuć.

12 L. Porębski, Między przemoca a godnością. Teoria polityczna Harolda D. Lasswella, Kraków 2007, s. 187.

13 J. Ellul, Propaganda. The Formation of Men's Attitude, New York 1973, s. 25-26.

14 Ibidem, s. 33.

15 Ibidem, s. 38.

16 Ibidem, s. 73.

17 Ibidem, s. 33.

18 L. Porębski, op. cit., s. 189. 
Po latach intensywnego grania na emocjach mas, odwoływania się do pragnień i niskich instynktów oraz ich usprawiedliwiania, niezwykle trudno jest wtłoczyć je w spokojne ramy codziennego życia ${ }^{19}$.

Jak wspomniana teoria ma się do przekazów propagandowych państw centralnych doby Wielkiej Wojny? Bez wątpienia, w każdym z nich dyskurs dotyczący własnego narodu, jego antagonistów i sojuszników miał osobną specyfikę i wypływał z innych uwarunkowań. Poniżej pragnę prześledzić okoliczności, które zdeterminowały charakter wojennych przekazów propagandowych nie tylko w II Rzeszy, lecz również w państwie austro-węgierskim i Bułgarii.

Obraz Niemców, sugestywnie wykreowany w państwach Ententy, opierał się na wizji tego narodu jako współczesnych Hunów: barbarzyńców, którzy zaatakowali neutralną Belgię, niszczyli dobra kultury i nie przestrzegali praw ludności cywilnej ${ }^{20}$. W efekcie jednym z głównych celów propagandy wilhelmińskiej było udowodnienie, że Niemcy prowadzą wojnę w bardziej cywilizowany sposób niż ich wrogowie ${ }^{21}$. Bolączką monarchii habsburskiej była z kolei relatywna słabość militarna i wewnętrzne konflikty narodowościowe. Dlatego też propaganda tego kraju zmuszona była kłaść silny nacisk na unaocznianie przykładów wyższości bojowej i patriotyzmu żołnierzy cesarsko-królewskiej armii oraz słabości i śmieszności jej wrogów. Znienawidzona przez narody bałkańskie Bułgaria w swojej wojennej propagandzie starała się natomiast dyskredytować swoich bałkańskich rywali i pomijać milczeniem informacje o ich możnych sojusznikach ${ }^{22}$.

Jaką jednak konkretnie rolę we wspomnianej propagandzie odgrywać miało państwo carów? W dużym stopniu zależało to od pozycji zajmowanej przez imperium rosyjskie w hierarchii wrogów. Dla Niemiec i Austro-Węgier Rosja była, na równi z Francją i Wielką Brytanią, śmiertelnie groźnym przeciwnikiem, w starciach z którym oba państwa centralne znajdowały się od wybuchu wojny aż do separatystycznego traktatu pokojowego zawartego 3 marca 1918 roku. Bułgaria z kolei znalazła się w stanie wojny z Rosją w październiku 1915 roku, w praktyce jednak wojska bułgarskie ścierały się z siłami rosyjskimi tylko w drugiej połowie roku 1916, podczas kampanii w Dobrudży ${ }^{23}$.

19 J. Ellul, op. cit., s. 76.

20 P. Jelavich, German Culture in the Great War, [w:] European Culture in the Great War. The Arts, Entertainment, and Propaganda, 1914-1918, A. Roshwald, R. Stites (red.), Cambridge 1999, s. 42-47.

21 W. Coupe, German Cartoons of the First World War, „History Today” 1992, no. 42, s. 27-29.

22 E. Kelbetcheva, Between Apology and Denial: Bulgarian Culture during World War I, [w:] European Culture in the Great War. The Arts, Entertainment, and Propaganda, 1914-1918, A. Roshwald, R. Stites (red.), Cambridge 1999, s. 227.

23 M. Tanty, Bałkany w XX wieku. Dzieje polityczne, Warszawa 2003, s. 133; J. Dąbrowski, Wielka Wojna 1914-1918, t. 3, Poznań 2000, s. 105-117. 
W tworzeniu propagandowych wizerunków dużą rolę odegrał również stereotypowy obraz imperium carów, utrwalony w świadomości społecznej w poszczególnych państwach. Przekonanie o niższości cywilizacyjnej Rosjan oraz ich politycznej pasywności znalazło odzwierciedlenie w niemieckich narracjach o Rosji jako zdeprawowanej „słowiańskiej barbarii”, sterowanej przez koalicjantów z Ententy, dysponującej jedynie nieukierunkowaną, „brutalną siłą surowej masy". W optyce austriacko-węgierskiej państwo carów postrzegane było nade wszystko jako odwieczny, makiaweliczny rywal, wywierający za pomocą ideologii panslawizmu negatywny wpływ na słowiańskich poddanych wieloetnicznego imperium. W efekcie, w propagandzie Habsburgów państwo Romanowów z reguły przedstawiano jako mniej lub bardziej demonicznego, snującego intrygi przeciwnika. Z kolei w społeczeństwie bułgarskim państwo carów było postrzegane jako imperium, które niecałe pół wieku wcześniej pomogło Bułgarii wywalczyć niepodległość, a także jako państwo pełniące rolę pośrednika w kontakcie bałkańskich intelektualistów z dorobkiem kulturowym Zachodu. W związku z tym, bułgarscy propagandyści starali się nie eksponować faktu, iż Bułgaria, angażując się w wojnę, znalazła się po przeciwnej niż Rosja stronie barykady.

$\mathrm{W}$ rozwiniętym $\mathrm{w}$ drugiej połowie XIX $\mathrm{w}$. europejskim dyskursie satyrycznym Rosja wizualizowana była za pomocą trzech głównych obrazów: „Iwana”, aktualnie panującego cara oraz „rosyjskiego niedźwiedzia”. Postać „Iwana” nawiązywała do stereotypowego wizerunku rosyjskiego chłopa oraz do obrazu kozaka: skośnookiego, w futrzanej czapie, wymachującego nahajką. Karykatury poszczególnych carów z reguły wiernie oddawały ich posturę i rysy twarzy, a nawet cechy charakteru. Ich ubiór stylizowany był jednak na strój kozaka, zaś w rękach władcy Rosji dzierżyli knuty. Z kolei „rosyjski niedźwiedź” był przedstawiany jako drapieżnik, tresowane zwierzę na łańcuchu, często jednak po prostu jako jedno ze zwierząt w europejskim zwierzyńcu państw. Co ważne, w prasie państw bałkańskich, takich jak Bułgaria i Serbia, w narracjach dotyczących Rosji znacząco rzadziej ukazywano ją pod postacią zwierzęcia.

Jakie zmiany w ten dyskurs satyryczny wniosły lata pierwszej wojny światowej? Niewątpliwie, wpłynęła ona na hiperbolizację satyrycznych środków wyrazu. Świat dobrze znanych obrazów zabarwiony został od dawna nienotowanym patosem i jadem przesłań, które symbolicznie miały zohydzać i zabijać wroga.

W pracy prześledzę główne metafory i motywy wizualne obecne $\mathrm{w}$ wymienionych poniżej czasopismach satyrycznych, które reprezentowały wprawdzie różne profile polityczne i światopoglądowe, jednak nade wszystko lojalnie wspierały wysiłki rodzimej wojennej propagandy: 
Wykaz czasopism satyrycznych poddanych analizie

\begin{tabular}{|c|c|}
\hline Niemcy & $\begin{array}{l}\text { „Der Wahre Jacob” - czasopismo reprezentujące poglądy } \\
\text { socjaldemokratyczne24 } \\
\text { „Simplicissimus” - czasopismo liberalne, które w okresie Wielkiej Wojny } \\
\text { przybrało profil nacjonalistyczny }{ }^{25} \\
\text { „Kladderadatsch”- czasopismo o nastawieniu prawicowo-konserwatywnym²6 }\end{array}$ \\
\hline Austro-Węgry & $\begin{array}{l}\text { „Kikeriki” - czasopismo o profilu konserwatywnym, reprezentujące poglądy } \\
\text { antysemickie }{ }^{27}\end{array}$ \\
\hline Bułgaria & „Baraban” - czasopismo liberalno-konserwatywne ${ }^{28}$ \\
\hline
\end{tabular}

Źródło: opracowanie własne.

Pragnąc usystematyzować mnogość wątków narracyjnych i metafor, wydzieliłam dwa dominujące toposy państwa carów związane z wizją Rosji jako siły opatrznościowej. Skupię się na motywach Rosji-wybawcy oraz Rosji-państwa walczącego o pokój, jako egzemplifikacji mitu Dziadka Iwana oraz mitu rewolucji rosyjskiej.

\section{Dziadek Iwan}

Wywodzący się z języka bułgarskiego termin „Dziadek Iwan” (Дядо Иван) zamierzam traktować w znaczeniu nadanym mu w krajach bałkańskich - jako synonim Rosji, rozumianej jako państwo-wybawca oraz potężny obrońca i ostoja wiary prawosławnej. Określenie to miało prawdopodobnie upamiętniać postaci carów Iwana III (1462-1505) i Iwana IV Groźnego (1533-1584), a także ich zwycięstwa w wojnach toczonych ze Złotą Ordą oraz Imperium Osmańskim ${ }^{29}$. Termin ten zdobył największą popularność w okresie tzw. wojny bułgarskiej, w wyniku której Bułgaria w 1878 roku uzyskała niezależność. W utworach z tego okresu pojawiają się określenia Rosji jako mesjasza, zaś car

24 Wydawane w Hamburgu, a następnie w Stuttgarcie w latach 1879-1933. W latach I wojny światowej osiągało nakład ponad 160000 egzemplarzy.

25 Wydawane w Monachium w latach 1896-1967, z przerwą w okresie 1944-1954. Na początku XX w. osiągało nakład ok. 85000 egzemplarzy.

26 Wydawane w Berlinie w latach 1848-1944. W czasie I wojny światowej miało nakład ponad 40000 egzemplarzy.

27 Wydawane w Wiedniu w latach 1861-1933. U szczytu popularności osiągało nakład 25000 egzemplarzy.

28 Założone w Sofii w 1909 roku.

29 N. Aretov, Forging the Myth about Russia: Rayna, Bulgarian Princess, [w:] Semantyka Rosji na Bałkanach, J. Sujecka (red.), Warszawa 2011, s. 69. 
Aleksander II bywa przyrównywany do Jezusa, wskrzeszającego Łazarza. Co więcej, wspomniany topos w znaczącym stopniu opierał się na mitach Rosji -Trzeciego Rzymu i Rosji-obrońcy Słowiańszczyzny, stanowiących podstawę rosyjskiej ideologii mesjańskiej.

Mit o Dziadku Iwanie można również określić mianem mitu o carze-batiuszce, czyli potężnym i miłosiernym ojcu. Tak rozumiany, posiada wyraźny wydźwięk patriarchalny, świadczący o zakorzenieniu tego toposu w etosie kultury patriarchalnej, tradycyjnej, chłopskiej, a także w rosyjskim etosie imperialnym i realizowanej przez Rosję hard power oraz w idei silnego władcy i traktujących go niczym dobrego ojczulka pokornych poddanych. Zgodnie z jego przesłaniem, wartość Rosji kryje się w jej sile, uosabianej przez potęgę wojskową i władczy majestat jej monarchy. Rosja przychodzi w sukurs swoim prawosławnym i słowiańskim braciom i kieruje karzącą dłoń przeciw ich wspólnym wrogom. Walczy w imię ideałów religijnych narodowo-wyzwoleńczych, metaforycznie - „krwi i ziemi”. Ponieważ Rosję sławi się przede wszystkim za jej siłę, mit nie wyklucza tym samym pochwały wszelkich, nawet najokrutniejszych, działań, które prowadzą do pokonania wroga i manifestacji własnej potęgi: autorytaryzmu, pogardy i okrucieństwa wobec słabszych rywali, traktowania własnych narodów jako słabych i biernych aktorów sceny politycznej, zadowalających się rolą beneficjentów pomocy udzielanej przez możnych protektorów. Nie przeszkadza mu nawet wizja Rosji jako państwa nieeuropejskiego, odwołującego się do tak barbarzyńskich, azjatyckich narzędzi sprawowania władzy jak nahajka. Mit ten może obalić jedynie dowodząc, iż kraj ten jest $\mathrm{w}$ istocie kolosem na glinianych nogach.

Biorąc pod uwagę zasięg terytorialny omawianego mitu, można stwierdzić, iż na obszarze Europy siła jego oddziaływania nie wykroczyła poza obszar tzw. ziem ruskich oraz Bałkanów. Dlaczego nie rozpowszechnił się on w Europie Środkowej ani Zachodniej? Można przypuszczać, że mit o dobrym Dziadku Iwanie był i jest nie do pogodzenia z przeświadczeniem o Rosji jako państwie nie w pełni przynależącym do cywilizacji europejskiej, a przez to ułomnym, niegodnym miana protektora i „ojczulka” krajów cywilizowanych. W zachodnim dyskursie dotyczącym Rosji znaczącą rolę odgrywały takie problemy jak anachroniczny charakter samodzierżawia, rosyjskie zacofanie gospodarcze, ucisk chłopów, pijaństwo, zabobon i analfabetyzm ${ }^{30}$. Co więcej, w Niemczech czy cesarstwie austro-węgierskim poglądowi o zacofaniu Rosji towarzyszyły często hasła o niższości rasowej Rosjan oraz o niemieckim posłannictwie kulturowym wśród Słowian.

30 L. Wolff, Inventing Eastern Europe. The Map of Civilization on the Mind of the Enlightenment, Stanford 1994, s. 130-170; E. Dmitrów, Obraz Rosji i Rosjan w propagandzie narodowych socjalistów 1933-1945. Stare i nowe stereotypy, Warszawa 1997, s. 113-114; A. Moser, Land der unbegrenzten Unmöglichkeiten. Das Schweizer Russland- und Russenbild vor der Oktoberrevolution, Zürich 2006, s. 300-312. 
W społeczeństwie serbskim czy bułgarskim szereg cech wyróżniających Rosję spomiędzy „oświeconych” państw Europy, takich jak przywiązanie do rodzimych tradycji, waloryzowano pozytywnie, dlatego też wizerunek Rosji jako batiuszki nie raził tam swoją archaicznością ${ }^{31}$. Zachodni Europejczycy, w tym Niemcy, starali się natomiast unikać sugestii, iż zacofana, samodzierżawna Rosja kiedykolwiek odegrała w ich dziejach rolę wyzwoliciela.

Prześledźmy kilka motywów wizualnych, obecnych w dyskursie prasowym doby Wielkiej Wojny, w których znalazł odzwierciedlenie opisany topos. Z oczywistych powodów modelowy obraz Rosji jako Dziadka Iwana znaleźć możemy w omawianym okresie w prasie serbskiej.

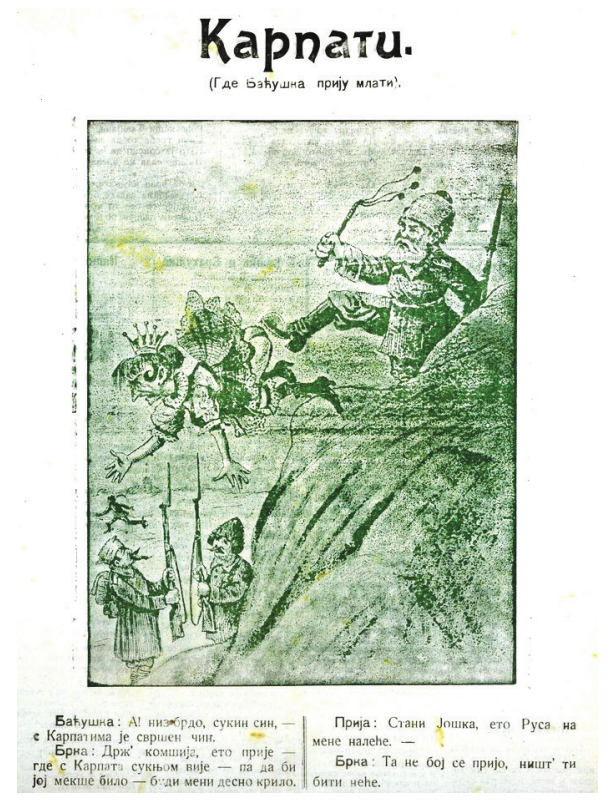

Ilustracja 1. „Ojczulek: Oj! Spada w dół, suka zła - w Karpatach wypełniona misja ma. Brka: Tak, sąsiedzie, zgadza się - gdy w jej suknię wicher dmie - by się jeszcze osłabiła - niech pomoże twoja siła. Prija: Zatrzymaj się, Joszko, bo dogonią mnie Rosjanie. - Brka: Nie bój się, Prijo, nic ci się nie stanie"

Źródło: Карпати (Где баћ ушка прију млати), „Брка” 1915, 26.04., s. 4.

31 Д. Чавдарова, Миф России и стереотип русского в болгарской культуре по сравнению с польским стереотипом, [w:] Polacy w oczach Rosjan - Rosjanie w oczach Polaków, R. Bobryk, J. Faryno (red.), Warszawa 2000, s. 201-203; H.G. Oroschakoff, Die Battenberg Affäre. Leben und Abenteuer des Gavriil Oroschakoff oder eine russisch-europäische Geschichte, Berlin 2007, s. 264-265. 
W okolicznościach mniej oczywistych pojawia się on jednak również $\mathrm{w}$ - antyrosyjskiej siłą rzeczy - prasie bułgarskiej. Na jej łamach motyw ten odnosi się do wizerunku Rosji jako mocarstwa, które jest politycznym adwersarzem, ale nie wrogiem. Uwidocznił się on zwłaszcza w związku z kampanią bułgarsko-rumuńską, w której Rosja z ociąganiem wsparła słabą militarnie Rumunię. Szereg karykatur opisujących przebieg walk na froncie bałkańskim przedstawia „Dziadka Iwana” pogardliwie wypowiadającego się o swoim sojuszniku i niechętnego perspektywie udzielania mu pomocy.

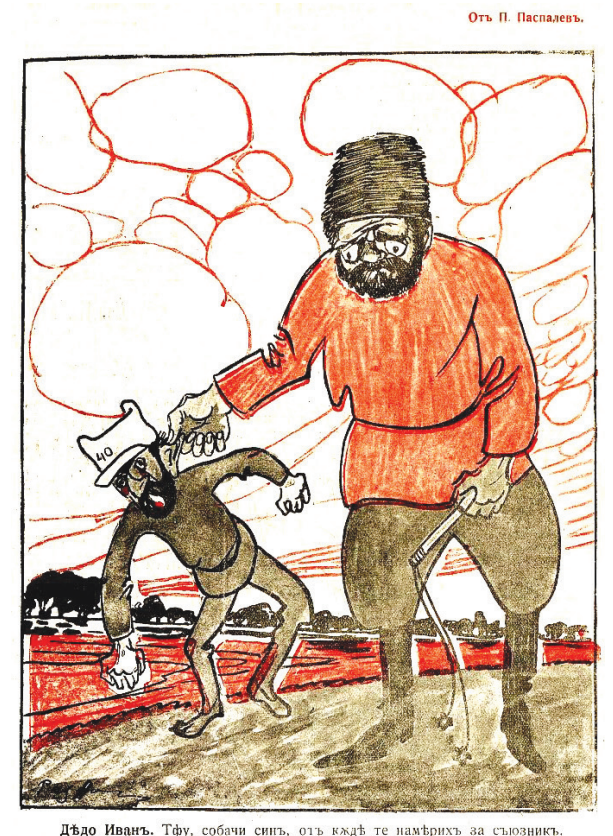

Ilustracja 2. „Tfu, sobaczy synu, na cholerę mi taki sojusznik”

Źródło: П. Паспалев, bez tytułu, „Барабан” 1916, 17.09., s. 8.

\section{Rewolucja rosyjska}

Drugim z wyodrębnionych przeze mnie toposów jest obraz Rosji jako wizjonera nowego świata. Motyw ten okazuje się istotny z kilku powodów. Po pierwsze, ponieważ idee powszechnego pokoju, rozbrojenia oraz walki z niesprawiedliwością i imperializmem odegrały kluczową rolę w ciągu minionych stu lat dziejów Rosji i ZSRR i znacząco wpłynęły na sposób postrzegania tego kraju, zaś na długo przed rewolucją stanowiły podskórną składową „idei rosyjskiej”. 
Wizje te można bowiem wpisać w logikę rdzennie rosyjskiego mitu o Rosji jako „duszy świata”. Dobrze oddają go słowa Fiodora Dostojewskiego, zgodnie z którymi „tylko duch rosyjski otrzymał w darze ogólnoludzki charakter, misję na przyszłość: zgłębić i zjednoczyć całą wielorakość narodów i usunąć wszystkie sprzeczności między nimi”; „powołaniem Rosji jest głoszenie idei ogólnego zjednoczenia świata i powszechnej miłości ludzi”32. Analogiczną myśl wyraził wcześniej Piotr Czaadajew, który nazwał Rosję krajem bez historii ani utrwalonego kulturowego kształtu, dzięki temu jednak zdolnym zburzyć to, co dotychczasowe, stworzyć lub wchłonąć dowolne idee, przyswoić nowe prawdy, religie, formy ustrojowe, a także ponieść je innym narodom. Znajomość wspomnianych aspektów „rosyjskiej idei” pozwala nam chociażby dostrzec głębszy sens pokojowych inicjatyw wysuwanych przez cara Mikołaja II. To on był pierwszym na świecie przywódcą, który w 1899 roku wyszedł z ideą powszechnego rozbrojenia, za co wśród opinii publicznej na Zachodzie zyskał sobie ironiczne miano „anioła pokoju”.

Po drugie, warto śledzić wspomniany topos, ponieważ stanowi on ciekawy punkt odniesienia w badaniach nad specyfiką mitu o Dziadku Iwanie. Nietrudno dostrzec, iż oba mity tworzą niejako dwa wymiary tej samej „idei rosyjskiej”, wyrosłej na koncepcjach rosyjskiego mesjanizmu, równocześnie jednak istnieją między nimi wyraźne sprzeczności. W odróżnieniu od patriarchalnego mitu o Dziadku Iwanie mit o Rosji-„,duszy świata” nosi w sobie komponent demokratyczny, egalitarny. Rosyjski rewolucjonista to człowiek z ludu, który nie tylko występuje z pozycji uciśnionego, lecz i utożsamia się z uciśnioną ludzkością. Odcina się on od działania w wąskich kategoriach narodu, religii, państwa; wartości, o które walczy, mają charakter ogólnoludzki. Jest zwiastunem nowej, sprawiedliwej rzeczywistości, ucieleśniającej ideały powszechnej wolności, równości, braterstwa.

Po trzecie wreszcie, wniknięcie w okoliczności, które towarzyszyły kształtowaniu się narracji o Rosji jako o wizjonerze nowego porządku, pozwala nam uzmysłowić sobie, że proces kształtowania się mitów bywa żmudny i paradoksalny. Należy pamiętać, iż państwami, które jako pierwsze zanegowały wspomnianą wizję, byli koalicjanci Rosji, zaś tymi, które ją podchwyciły - właśnie kraje centralne.

Gdy obejmujący władzę bolszewicy wyrazili gotowość zawarcia separatystycznego pokoju, motyw Rosji jako mocarstwa walczącego o wzniosłe ideały pojawił się $\mathrm{w}$ propagandzie wszystkich omawianych przeze mnie państw. Szczególnie eksponowany i waloryzowany był on jednak przede

32 Cyt. za: M. Broda, Rosja-,,dusza świata”, [w:] Idei w Rossii, Idee w Rosji, Ideas in Russia, t. 6, J. Kurczak (red.), Łódź 2007, s. 270. 
wszystkim w prasie niemieckiej, zwłaszcza socjalistycznej. Na jejłamach zagościł m.in. obraz rosyjskiego Samsona, burzącego filary ancient regime'u, a także prostodusznego Iwana z gałązką oliwną.

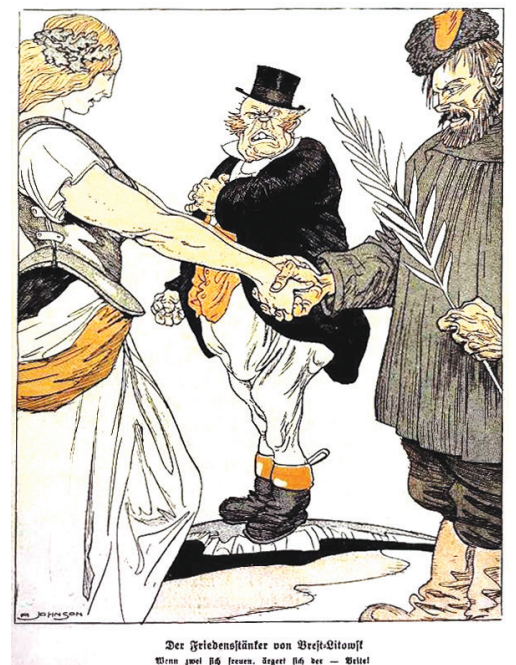

Ilustracja 3. „Gdzie dwóch się cieszy, tam trzeci się złości”

Źródło: Der Friedensstänker von Brest-Litowsk, „Kladderadatsch” 1918, nr 2.

Jedną z ciekawych wizualizacji nowej, bolszewickiej Rosji stanowi ilustracja opublikowana w „Der Wahre Jacob” w styczniu 1918 roku.

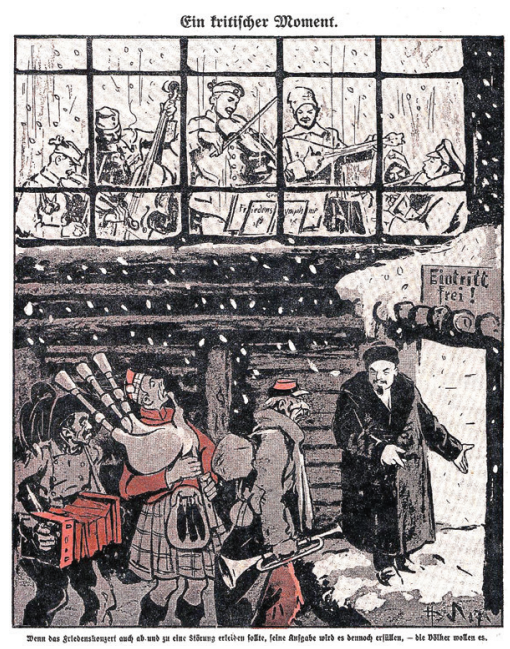

Ilustracja 4. „Nawet jeśli koncert pokojowy od czasu do czasu przeżywa problemy, wypełni jednak swoją misję, ponieważ tego oczekują narody"

Źródło: Ein kritischer Moment, „Der Wahre Jacob” 1918, nr 822, strona tytułowa. 
Państwo radzieckie reprezentują na niej dwie postacie: Lenin, stylizowany na dobrze wychowanego i gościnnego człowieka Orientu, i pogodny żołnierz rosyjski uczestniczący $\mathrm{z}$ przedstawicielami państw centralnych $\mathrm{w}$ koncercie pokojowym. Pozytywny wydźwięk omawianego obrazu potęguje fakt, że został on wpisany w wizję nocy wigilijnej. Jej atmosferę tworzy prószący śnieg, trzej goście (reprezentujący państwa Ententy) stojący u drzwi niczym orszak trzech króli oraz rozświetlona izba z domownikami, którzy, na wzór przedstawicieli dobrej niemieckiej rodziny, muzykują wspólnie przy kominku.

$\mathrm{W}$ tej ostatniej wizji kryje się jednak pewien dysonans. Czy obraz skośnookiego Lenina, nawet udrapowanego w szaty statecznego gospodarza, nie mógł w niemieckim czytelniku wywołać mimowolnych skojarzeń z rosyjskim Tamerlanem, którym straszono Niemców w roku 1914? Czy niemożność zawarcia $\mathrm{w}$ dobrym bohaterze, jakim miał jawić się Lenin, odniesień do kodów kulturowych zarazem wiązanych z Rosją i odbieranych pozytywnie, nie świadczyła o bezsilności artysty, który miast pokazać satyryczny pazur, zmuszony był ograniczyć się do roli schlebiającego portretowanym, „politycznie poprawnego" ilustratora?

\section{Nie wierzcie Iwanowi, czyli demitologizacja obrazu}

W tym miejscu pragnę poruszyć trzeci problem związany z obrazem Rosji jako siły opatrznościowej, a mianowicie kwestię jego demitologizacji. Wśród omawianych propagandowych dyskursów najmniej motywów pozytywnie waloryzujących Rosję dostrzec można w dyskursie austriackim. Rosja, carska czy bolszewicka, praktycznie w ogóle nie funkcjonowała w prasie austriackiej jako symbol opatrzności, wyraźnie natomiast jako państwo będące tej idei zaprzeczeniem. Widać to jasno na przykładzie narracji związanych z wizerunkiem Rosji carskiej jako kolosa na glinianych nogach, zaś Rosji bolszewickiej jako zwodziciela, szarlatana, fałszywego mesjasza czy wręcz szatana.

Choć obraz Rosji jako kolosa na glinianych nogach stał się leitmotivem satyrycznego dyskursu na temat państwa carów konstruowanego w prasie wszystkich państw centralnych, w moim odczuciu najsilniejszy wyraz znalazł on właśnie w satyrze austriackiej. Jedną z najbardziej rozwiniętych satyrycznych polemik z obrazem Rosji jako Dziadka Iwana przedstawia rysunek Kolos na glinianych nogach, opublikowany na początku wojny w konserwatywnym, antysemickim czasopiśmie „Kikeriki”. 
Pokój z Iwanem. Rosja jako siła opatrznościowa w propagandzie...

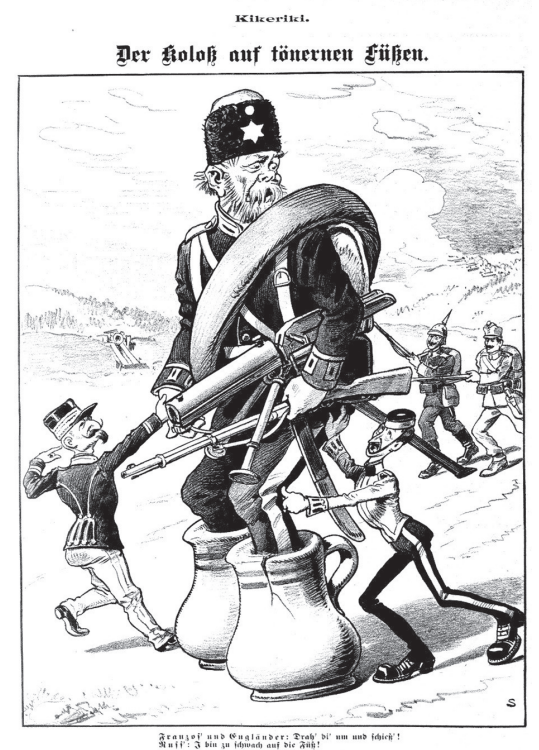

Ilustracja 5. „Francuz i Anglik: Odwróć się i strzelaj!; Rosjanin: Mam za słabe nogi!”.

Źródło: Der Kolo $\beta$ auf tönernen Füßen „Kikeriki” 1914, nr 34.

Wielki, stary Iwan, ukazany w karykaturze, ugina się pod ciężarem źle dobranego ekwipunku i rozkazów, wydawanych ze wszystkich stron, i w efekcie niezdolny jest nawet do obrony przed słabszym z pozoru wrogiem. Interesującym artefaktem, umieszczonym na czapce Rosjanina, jest sześcioramienna gwiazda, przypominająca gwiazdę Dawida. Interpretacja tego, w jakim znaczeniu została ona użyta na rysunku, nie jest oczywista. Być może za jej pomocą karykaturzysta chciał nawiązać do faktu, że przystąpieniu Rosji do wojny towarzyszyły deklaracje poparcia dla rządu ze strony wszystkich ugrupowań politycznych oraz grup narodowościowych imperium, włączając silnie dyskryminowanych przez carat Żydów ${ }^{33}$. Tym samym, gwiazda Dawida mogła posłużyć jako prześmiewcza metafora narodowej, cudownie ustanowionej jedności rosyjskiego społeczeństwa.

Równie negatywne dla Rosji przesłanie niosły metafory Dziadka Mroza, uosabiającego zimę i śmierć, topiącego się pod wpływem mocy, którą promieniują armie koalicji antyrosyjskiej. Z kolei zjadliwą, antysemicką satyrę na wzniosłe idee, głoszone przez cara czy komunistów, stanowiły np. karykatury ukazujące Mikołaja II jako Janusa, zaś Lwa Trockiego pod postacią Szczurołapa z Hameln.

33 Documents of Russian History 1914-1917, http://archive.org/stream/documentsofrussi027937mbp/documentsofrussi027937mbp_djvu.txt [dostęp: 20.02.2015]. 


\section{Der rufitifche Raffenfänger}

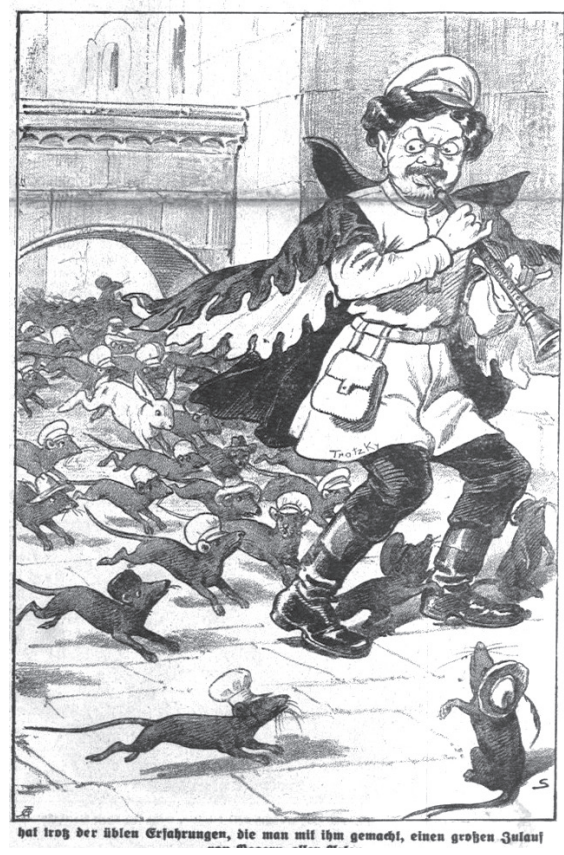

Ilustracja 6. „Mimo złych doświadczeń z nim związanych, skusił do siebie kolejne watahy gryzoni"

Źródło: Der russische Rattenfänger, „Kikeriki” 1918, 10.02.

Podsumowując, pragnę zwrócić uwagę na trzy kwestie. Po pierwsze, w okresie I wojny światowej w poszczególnych krajach koalicji antyrosyjskiej dyskurs dotyczący Rosji determinowany był przez historię, geopolitykę i mentalność tworzących go społeczeństw. Z tego powodu narracje o tym państwie zawierały nierzadko skrajnie odmienne konotacje znaczeniowe i bazowały na odmiennych motywach. Tworząc optymistyczne dyskursy o Rosji, w Bułgarii odwoływano się głównie do toposu Dziadka Iwana, niechętnego ingerencji na Bałkanach, w Niemczech zaś do wizji chłopów i bolszewików, walczących o pokój. Z kolei w Austrii głównie szydzono z wymienionych wyżej „szlachetnych” interpretacji rosyjskich poczynań.

Po drugie, obrazy Rosji, prezentowane na łamach opisanych czasopism, siłą rzeczy tworzone były pod światopogląd ich odbiorców: socjalistyczny, konserwatywny, liberalny, nacjonalistyczny, antysemicki lub antykomunistyczny.

Po trzecie, opisywane toposy inspirowane były w przeważającej mierze językowymi i wizualnymi schematami utrwalonymi na długo przed rokiem 
1914. Ich siłą była rozpoznawalność i moc odwoływania się do toposów związanych z państwem carów, tkwiących w pokładach wyobraźni masowej. Tak właśnie działo się w przypadku mitu o Dziadku Iwanie. W ramy metafor trudno było jednak ubrać rzeczywistość nową, nieznaną i niepewną, tym zaś był świat wyłaniający się z gruzów samodzierżawnej monarchii. Bolszewicy, reprezentanci nowego świata i jego pozytywni bohaterowie, początkowo jawili się jako twarze, za którymi nie kryła się żadna spójna symboliczna narracja, żadna koherentna „wielka opowieść”. Fakt ten potwierdza tezę, zgodnie z którą rodzącej się rzeczywistości zdefiniować się nie da, poznać ją można tylko „z oddali”.

\section{Bibliografia}

Aretov N., Forging the Myth about Russia: Rayna, Bulgarian Princess, [w:] Semantyka Rosji na Bałkanach, J. Sujecka (red.), Warszawa 2011, s. 69-89.

Broda M., Rosja-,dusza świata”, [w:] Idei w Rossii, Idee w Rosji, Ideas in Russia, t. 6, J. Kurczak (red.), Łódź 2007, s. 264-275.

Campbell J., Bohater o tysiacu twarzy, Poznań 1997.

Coupe W., German Cartoons of the First World War, „History Today” 1992, no. 42 , s. 23-30.

Dąbrowski J., Wielka Wojna 1914-1918, t. 3, Poznań 2000.

Dmitrów E., Obraz Rosji i Rosjan w propagandzie narodowych socjalistów 1933-1945. Stare i nowe stereotypy, Warszawa 1997.

Documents of Russian History 1914-1917, http://archive.org/stream/documentsofrussi027937mbp/documentsofrussi027937mbp_djvu.txt [dostęp: 20.02.2015].

Ellul J., Propaganda. The Formation of Men's Attitude, New York 1973.

Gromadzki G. i in., Ludzie-historia-polityka. Polska i Niemcy w oczach Rosjan, Warszawa 2012.

Janeke K. (red.), Unsere Russen, unsere Deutschen. Bilder vom Anderen 1800 bis 2000, Berlin 2008.

Jelavich P., German Culture in the Great War, [w:] European Culture in the Great War. The Arts, Entertainment, and Propaganda, 1914-1918, A. Roshwald, R. Stites (red.), Cambridge 1999, s. 32-57.

Kelbetcheva E., Between Apology and Denial: Bulgarian Culture during World War I, [w:] European culture in the Great War. The arts, entertainment, and propaganda, 1914-1918, A. Roshwald, R. Stites (red.), Cambridge 1999, s. $215-242$.

Klaczko J., Dwaj kanclerze i inne studia dyplomatyczne, Kraków 2009.

Moser A., Land der unbegrenzten Unmöglichkeiten. Das Schweizer Russlandund Russenbild vor der Oktoberrevolution, Zürich 2006. 
Oroschakoff H.G., Die Battenberg Affäre. Leben und Abenteuer des Gavriil Oroschakoff oder eine russisch-europäische Geschichte, Berlin 2007.

Porębski L., Między przemoca a godnością. Teoria polityczna Harolda D. Lasswella, Kraków 2007.

Rachtan P., Rosja - Niemcy, dwaj sasiedzi, http://kontrateksty.pl/index.php?action=show\&type $=$ quick\&page $=77$ [dostęp: 23.04.2016].

Tanty M., Bałkany w XX wieku. Dzieje polityczne, Warszawa 2003.

Wolff L., Inventing Eastern Europe. The Map of Civilization on the Mind of the Enlightenment, Stanford 1994.

Чавдарова Д., Миф России и стереотип русского в болгарской культуре по сравнению с польским стереотипом, [w:] Polacy w oczach Rosjan - Rosjanie w oczach Polaków, R. Bobryk, J. Faryno (red.), Warszawa 2000, s. $199-212$.

http://de.statista.com/statistik/daten/studie/177126/umfrage/personengruppen-die-als-nachbarn-unangenehm-waeren/ [dostęp: 1.07.2015].

http://de.statista.com/statistik/daten/studie/292792/umfrage/umfrage-zucharaktereigenschaften-von-wladimir-putin/ [dostęp: 1.07.2015].

https://www.evangelisch.de/inhalte/91843/27-01-2014/gauck-erinnerung-leid -der-russen-im-zweiten-weltkrieg-wach-halten [dostęp: 1.07.2015].

http://www.freundederkuenste.de/aktuelles/reden-ist-silber/meinung/joachim-gauck-missbraucht-sein-amt-konstantin-wecker-und-rainer-kahni -sind-empoert.html [dostęp: 10.07.2015].

http://www.welt.de/reise/article128791869/Warum-Russen-die-unbeliebtesten-Touristen-sind.html [dostęp: 1.07.2015].

\begin{abstract}
The purpose of this article is to trace the ambiguous images of Russia which had been presented after October Revolution in propaganda of Central Powers. Because of the Bolsheviks' peace slogans this country suddenly became the most desired ally of Germany, Austria-Hungary and Bulgaria. The autor aims to answer the following questions:

- Which narratives connected to Russia did dominate in German society in 1917-1918?

- To which extent were they similar and in which different from the leading narratives in such countries as Austria-Hungary and Bulgaria?

- What was the background of the mentioned narratives and images?

The author distinguished two major motifs connected to the image of Russia as a kind of providential force:

1) of Russia-the-Saviour (as an exemplification of the myth of "Grandpa Ivan"),

2) of Russia-a-fighter-for-peace (as a continuation of the myth of Russian Revolution).
\end{abstract}

Keywords: Russia, Central Powers, revolution, peace, propaganda, World War I 